\title{
Investigations of Latvian Illite/Kaolinite Clays Irradiated Under Action of Accelerated Electrons
}

\author{
Davis CONKA ${ }^{1 *}$, Liga AVOTINA ${ }^{1}$, Ruta SVINKA ${ }^{2}$, Visvaldis SVINKA ${ }^{2}$, \\ Larisa BAUMANE ${ }^{1,3}$, Anna TRUBACA-BOGINSKA ${ }^{4}$, Valentina KINERTE ${ }^{1}$, \\ Gunta KIZANE ${ }^{1}$
}

\author{
${ }^{1}$ University of Latvia, Institute of Chemical Physics, Jelgavas str.1, Riga, Latvia \\ ${ }^{2}$ Riga Technical University, Institute of Silicate Materials, P.Valdena str. 3/7, Riga, Latvia \\ ${ }^{3}$ Latvian Institute of Organic Synthesis, Aizkraukles str. 21, Riga, Latvia \\ ${ }^{4}$ University of Latvia, Faculty of Chemistry, Jelgavas str.1, Riga, Latvia \\ crossref http://dx.doi.org/10.5755/j01.ms.26.1.21446
}

Received 14 August 2018; accepted 15 December 2018

\begin{abstract}
Natural clay is a perspective material for application as sorbents for wastewater treatment as well as for sorption of radionuclides, where the properties of the clays can be changed under influence of ionizing radiation. For application of Latvian illite/kaolinite clays for isotope sorption it is important to characterize the physic-chemical properties of preprepared air dried clays. Two fractions of the illite clays were selected. A fraction with grain size $100 \mu \mathrm{m}\left(\mathrm{SiO}_{2}\right.$ content $60.9 \pm 1.5 \mathrm{wt} . \%$, specific surface area $\left.35 \mathrm{~m}^{2} / \mathrm{g}\right)$ and a sand free fraction $-2 \mu \mathrm{m}\left(\mathrm{SiO}_{2} 47.7 \pm 1.9 \mathrm{wt} . \%\right.$, specific surface area $\left.38 \mathrm{~m}^{2} / \mathrm{g}\right)$. Selected fractions were irradiated with accelerated electrons (5 MeV, ELU-4, Salaspils, absorbed dose up to $500 \mathrm{kGy}$ ). Non-irradiated and irradiated clays were analysed with means of Fourier transform infrared (FT-IR) spectrometry.

Keywords: illite/kaolinite, accelerated electrons, irradiation, spectrometry.
\end{abstract}

\section{INTRODUCTION}

Clays and ceramics have important role as building and construction materials [1]. Various natural clays are considered for treatment of wastewater containing heavy metal $[2,3]$ ions, as well as radioactive elements, such as ${ }^{137} \mathrm{Cs}$ [4] and ${ }^{60} \mathrm{Co}$ [5]. There is perspective of clay application for in situ immobilization of metal ions in soil [6].

Latvian natural clays are commonly used as building materials and are suggested for use in the hydrogen cells [7]. For spreading the field of application of the Latvian natural clays, the radiation modification and investigations of modified clays is necessary.

In this research we characterize the initial structure and composition of differently fractionized Liepa clay as well as perform radiation modification under action of accelerated electrons. Irradiated clays are analysed with spectrometric methods.

\section{EXPERIMENTAL}

Devonian clay of Liepa deposit was chosen as a raw material. Two fractions of clay $<100 \mu \mathrm{m}$ and $\leq 2 \mu \mathrm{m}$ were prepared for the irradiation with accelerated electrons. The coarser clay fraction was prepared by screening of natural clay suspension without electrolyte and it contains $55 \mathrm{wt} . \%$ of solid particles. Dispersion of clay particles aggregates was carried out in the quick mixer $1000 \mathrm{rpm}$. After dispersing, the suspension was separated using a vibrating screen Analysette 3 PRO and a 100 micrometre sieve. The suspension obtained after screening was dried in the temperature $60^{\circ} \mathrm{C}$. The second fraction was also from natural clay obtained by sedimentation method using suspension of clay and $0.1 \%$ of sodium pyrophosphate as a dispersing agent and additional an ultrasonic dispersion. After dispersing the suspension, pour $1 \mathrm{~L}$ into a measuring cylinder and make up to the mark. Sedimentation time in the cylinder was 3 days. Pour the top of the suspension after this time into the vessel and evaporate the water by drying. Specific surface was determined by applying BrunauerEmmet-Teller (BET) method.

Irradiation was performed under action of accelerated electrons with energy up to $5 \mathrm{MeV}$ (linear electron accelerator facility, ELU-4, in Salaspils, Latvia). Samples were placed perpendicular to the electron beam. Irradiation dose was approximately $1 \mathrm{kGy} / \mathrm{s}$, absorbed doses up to $4900 \mathrm{kGy}$, samples were held at room temperature.

Both fractions prior and after irradiation were investigated with infrared and electron spin resonance method. X-ray fluorescence spectrometer Bruker Tiger S8 was used to determine the chemical composition of both fractions. Crystalline phase composition was analysed with Bruker D8 Advance X-ray diffractometer $\mathrm{Cu} \mathrm{K \alpha}$ radiation $(\lambda=1.5418 \AA$ ) LynxEye detector operating at $40 \mathrm{kV}$ and $40 \mathrm{~mA}$ with $0.6 \mathrm{~mm}$ divergence slit, $8.0 \mathrm{~mm}$ anti-scatter slit $2 \Theta$ range from $3^{\circ}$ to $70^{\circ}$ with increments of $0.02^{\circ}$ and a counting time of $0.5 \mathrm{~s}$ per step. Thermogravimeter/Differential thermal analysis device SEIKO EXSTAR 6300 was used to analyse the water

\footnotetext{
* Corresponding author. Tel.: +371-67033937; fax: +371-67033937.

E-mail address: conkadavis@gmail.com (D. Conka)
} 
release process from the clay structure. Clays were heated in air, diluted with argon, gas flow $200 \mathrm{~mL} / \mathrm{min}$. The heating products were guided to the infrared spectrometer (Bruker Vertex 70v) and the Fourier transform infrared (FTIR) spectra were recorded, resolution $\pm 2 \mathrm{~cm}^{-1}$, spectral range $600-4000 \mathrm{~cm}^{-1}$. Chemical bonds in non-irradiated and irradiated clays characterized with attenuated total reflection FTIR (ATR-FTIR), Bruker Vertex 70v, resolution $\pm 2 \mathrm{~cm}^{-1}$, spectral range $400-4000 \mathrm{~cm}^{-1}$, vacuum $2.95 \mathrm{hPa}$. ESR spectra are recorded using Bruker BioSpin X-band spectrometer, microwave frequency $9.8 \mathrm{GHz}$, microwave power $0.2 \mathrm{~mW}$, operating at room temperature, Bruker ER $221 \mathrm{TUB} / 3$ clear fused quartz quality sample tubes. Reference marker ER 4119HS-2100 with g-factor $1.9800 \pm 0.0005$, concentration of electrons $1.15 \times 10^{-3} \%$.

\section{RESULTS AND DISCUSSION}

The characterization of the specific surface area of the two selected clay faction was performed with BET method and the specific surface area for a fraction with grain diameter $100 \mu \mathrm{m}$ was $35 \mathrm{~m}^{2} / \mathrm{g}$ and for a sand free fraction $2 \mu \mathrm{m} 38 \mathrm{~m}^{2} / \mathrm{g}$. The analysis with means of XRF of two fractions of Liepa clay show that they both contain $\mathrm{SiO}_{2}$, $\mathrm{Al}_{2} \mathrm{O}_{3}, \mathrm{Fe}_{2} \mathrm{O}_{3}, \mathrm{MgO}, \mathrm{CaO}, \mathrm{P}_{2} \mathrm{O}_{5}, \mathrm{TiO}_{2}, \mathrm{~K}_{2} \mathrm{O}$.

Table 1. XRF data for content of oxides in Liepa clays with grain diameter $100 \mu \mathrm{m}$

\begin{tabular}{|c|c|}
\hline Oxide & Oxides content in Liepa clay, \% \\
\hline $\mathrm{SiO}_{2}$ & $64 \pm 2$ \\
\hline $\mathrm{Al}_{3} \mathrm{O}_{3}$ & $20.9 \pm 1.5$ \\
\hline $\mathrm{K}_{2} \mathrm{O}$ & $5.5 \pm 0.4$ \\
\hline $\mathrm{Fe}_{3} \mathrm{O}_{3}$ & $5.39 \pm 0.19$ \\
\hline $\mathrm{MgO}$ & $1.86 \pm 0.03$ \\
\hline $\mathrm{TiO}_{2}$ & $1.20 \pm 0.05$ \\
\hline $\mathrm{CaO}_{2}$ & $0.3 \pm 1.0$ \\
\hline $\mathrm{P}_{2} \mathrm{O}_{5}$ & $0.2 \pm 0.4$ \\
\hline
\end{tabular}

The biggest difference between a fraction with grain diameter $100 \mu \mathrm{m}$ and fraction with grain size $2 \mu \mathrm{m}$ is, that fraction with grain size $2 \mu \mathrm{m}$ do not contain $\mathrm{SiO}_{2}$.

The analysis of crystalline phase composition by the $\mathrm{X}$ ray diffractometry show that both fracions contain illite and kaolinite. In the $100 \mu \mathrm{m}$ Liepa clay fraction the quartz diffraction lines have the highest intensity. The X-ray diffractograms of 100 and $2 \mu \mathrm{m}$ fraction are presented in Fig. 1.

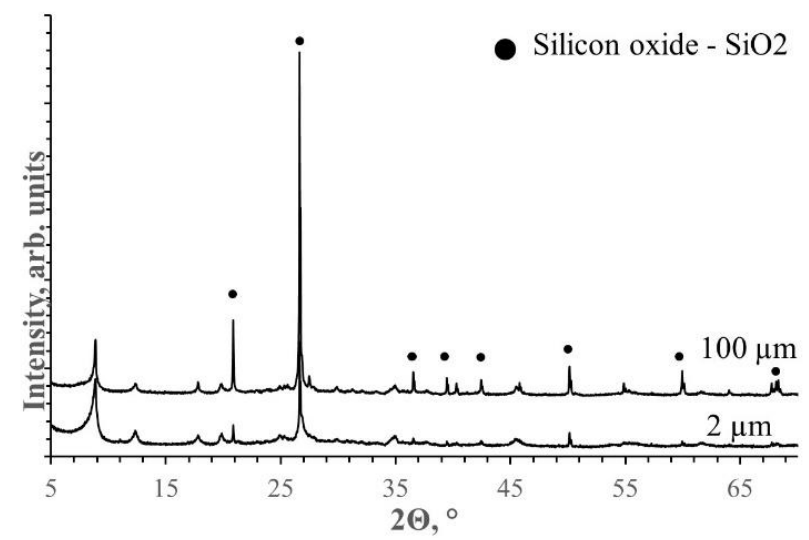

Fig. 1. X-ray diffractograms of the 2 and $100 \mu \mathrm{m}$ clay fractions
Thermal analysis of the Liepa clay allows to determine the water release steps, thermogravimetry/differential thermogravimetry curves of the $2 \mu \mathrm{m}$ clay fraction are shown in Fig. 2. The mass decrease is related with the desorption of water and dihydroxylation of clay minerals kaolinite and illite. The water peaks were registered while heating the clay with the coupled system TG-FTIR. The mass loss can be distinguished in four main steps with maximal mass decrease rate at around 340, 580, 750 and $840 \mathrm{~K}$, respectively. The water located in micropores is released in the temperatures up to $400 \mathrm{~K}$. Water molecules more closely bonded to the mineral structure are released in 500-600 K. Mass decrease from 700-900 K cam be related with elimination of the structural $\mathrm{OH}$-groups [8].

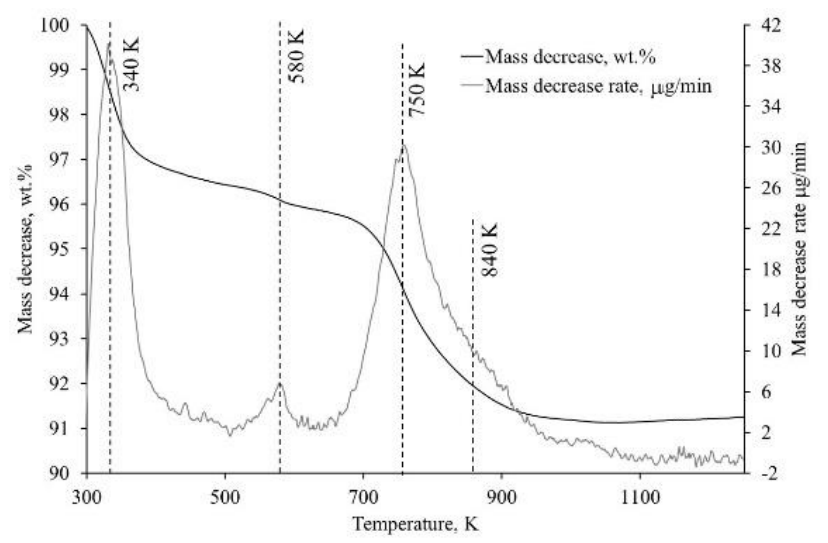

Fig. 2. Thermogravimetry, differential thermogravimetry of the $2 \mu \mathrm{m}$ Liepa clay fraction, heating rate $10 \mathrm{~K} / \mathrm{min}$

To understand impact of accelerated electrons to clay structure, FT-IR ATR analyses were performed for irradiated and non-irradiated Liepa clays.

In this study, non-irradiated and clays, irradiated with 20, 100, 200 and $500 \mathrm{kGy}$ were investigated for clay fraction with grain size $2 \mu \mathrm{m}$, and non-irradiated and clays, irradiated with 20,100, 200, 300, 500, 750, 1000, 1500, 2000 and $4900 \mathrm{kGy}$ for Liepa clays with grain size $100 \mu \mathrm{m}$.

Most of the chemical bonds for compounds determined by XRF analysis were determined using FT-IR ATR spectrometry. Oxide bonds at Fig. 3, Fig. 4 and Fig. 5 can be observed at different wavelengths. Chemical bonds corresponding to $\mathrm{Fe}_{2} \mathrm{O}_{3}$ can be observed at 490, 570 and $650 \mathrm{~cm}^{-1}[9,10] . \mathrm{Al}_{2} \mathrm{O}_{3}$ chemical bonds can be observed at 479, 713 and $453 \mathrm{~cm}^{-1}$ [11]. One $\mathrm{MgO}$ chemical bond can be observed at $548 \mathrm{~cm}^{-1}$ [12]. $\mathrm{CaO}$ bond is observed at $738 \mathrm{~cm}^{-1}$ [13]. Different chemical bonds for $\mathrm{P}_{2} \mathrm{O}_{5}$ can be observed at 600, 790, 930 and $1195 \mathrm{~cm}^{-1}$ [14]. But for $\mathrm{TiO}_{2}$ chemical bonds can be observed at 440 and $850 \mathrm{~cm}^{-1}$ [15].

The differences in FTIR spectra between irradiated and non-irradiated clays are determined. The main changes are in the intensities of different signals and these changes occur due to irradiation under action of accelerated electrons with energy up to $5 \mathrm{MeV}$.

Differences in spectrum between irradiated and nonirradiated clays, mostly, can be seen in the ranges $400-600 \mathrm{~cm}^{-1}$ and $800-1200 \mathrm{~cm}^{-1}$. The most differences between $100 \mu \mathrm{m}$ and $2 \mu \mathrm{m}$ clay fractions are due to amount of $\mathrm{SiO}_{2}$ in both clay fractions. In $100 \mu \mathrm{m}$ fraction, the amount of $\mathrm{SiO}_{2}$ is much higher. In FT-IR spectrum, $\mathrm{SiO}_{2}$ bonds can be observed at range of $900-1000 \mathrm{~cm}^{-1}$. A strong 
signal is at the frequency of $\sim 950 \mathrm{~cm}^{-1}$. The peak near $460 \mathrm{~cm}^{-1}$ can be assigned to the quartz $\left(\mathrm{SiO}_{2}\right)$ [16].

Irradiation dependent changes occur in free radical electrons in $2 \mu \mathrm{m}$ fraction. $100 \mu \mathrm{m}$ fraction no exact correlation between absorbed dose and free radicals occur.

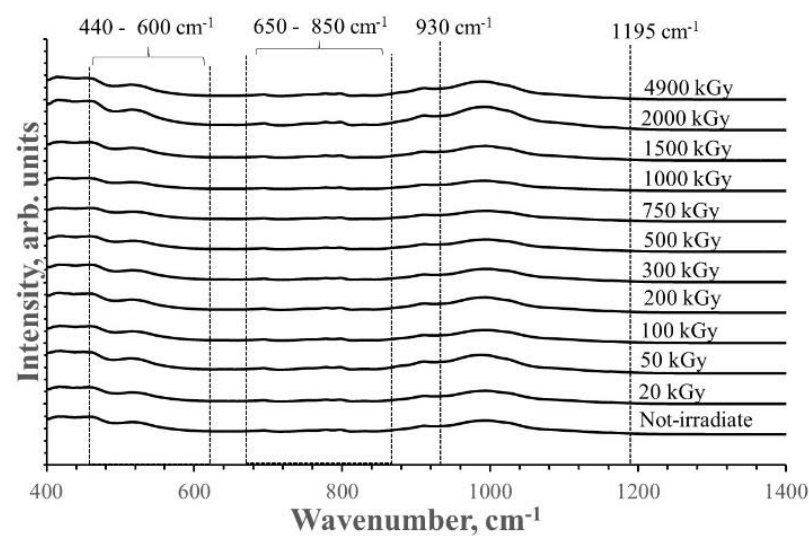

Fig. 3. FTIR spectra of $100 \mu \mathrm{m}$ clay fraction before irradiation and irradiated with absorbed doses up to $4900 \mathrm{kGy}$

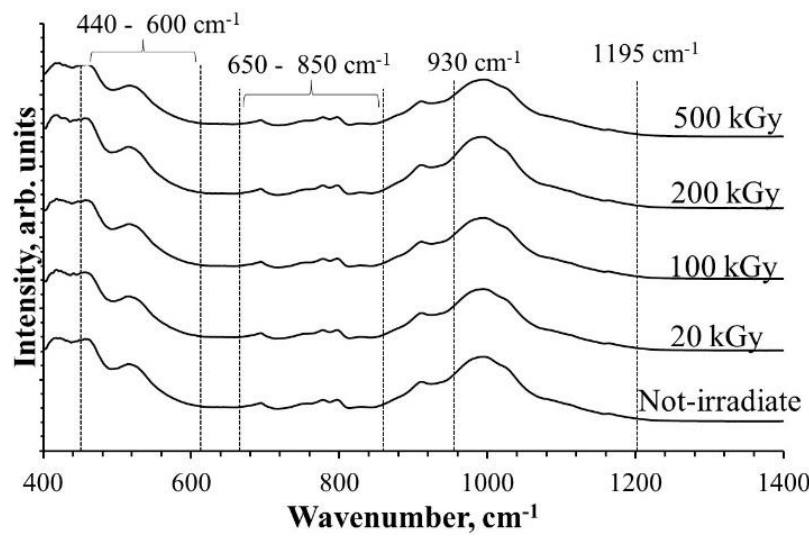

Fig. 4. FTIR spectra of $100 \mu \mathrm{m}$ clay fraction before irradiation and irradiated with absorbed doses up to $500 \mathrm{kGy}$

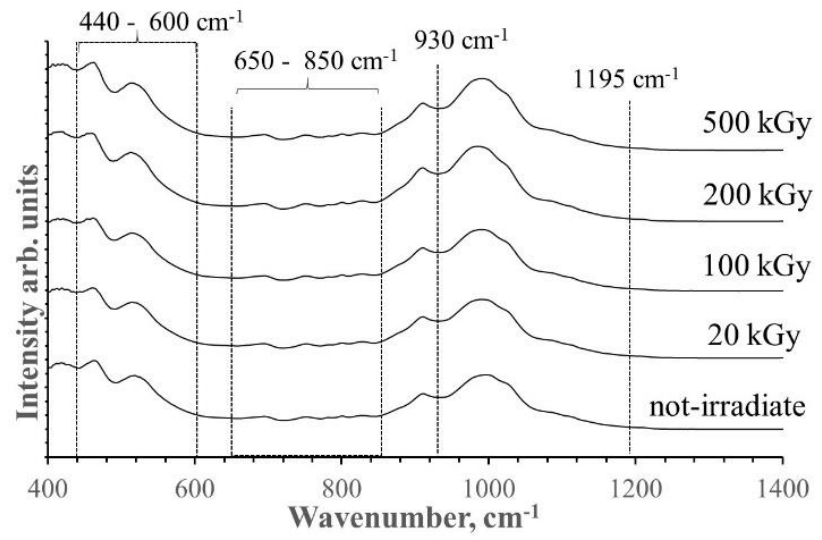

Fig. 5. FTIR spectra of $2 \mu \mathrm{m}$ clay fraction before irradiation and irradiated with absorbed doses up to $500 \mathrm{kGy}$

Analysis of free radicals in the $100 \mu \mathrm{m}$ fraction show that in the initial clay are several paramagnetic centres. Broad signals with g-factors around 4.2 indicate to presence of $\mathrm{Fe}^{3+}$ ions $[17,18]$ (Fig. 6 and Fig. 7). Several signals can be distinguished around the g-factor 2 (Fig. 6), such as electron hole located at $\pi$ orbital of an oxygen atom, $\mathrm{g}=2.001$, located at the vicinity of a Si-O bond $[19,20]$.
Irradiation of this fraction causes minor changes in the $\mathrm{Fe}^{3+}$ ion signal, while the signals around $\mathrm{g}=2$ are changing, but without visible dependency from the irradiation dose. This might be due the inhomogeneity of the material.

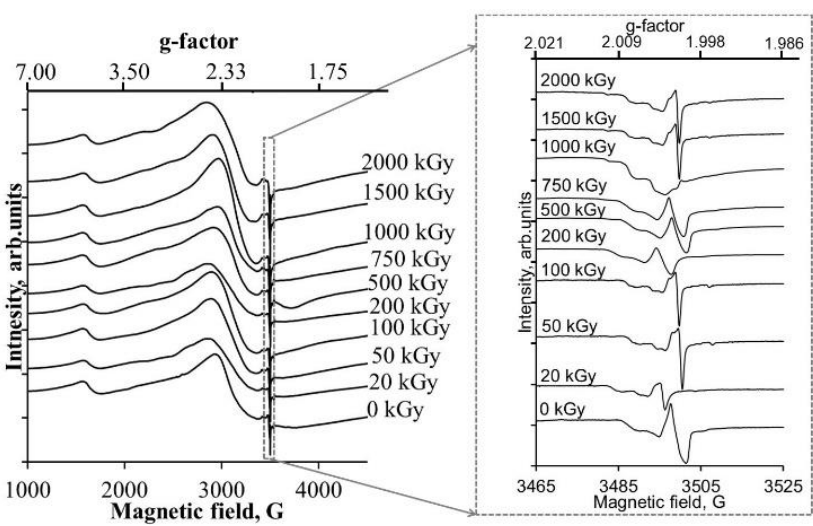

Fig. 6. ESR spectra of $100 \mu \mathrm{m}$ clay fraction before irradiation and irradiated with absorbed doses up to $500 \mathrm{kGy}$

In the ESR spectra of $2 \mu \mathrm{m}$ fraction the spectrum of non-irradiated clay is like to the spectrum $100 \mu \mathrm{m}$ clay (Fig. 6, Fig. 7). Fe ${ }^{3+}$ signal occurs as well; the value of gfactor is slightly changed. Difference occur in the case of irradiated clay. By removal of the $\mathrm{SiO}_{2}$ fraction and change of the preparation method, the radiation stability of paramagnetic centre with $g=2.001$ can be estimated. Slight changes occur, but the overall concentration is not significantly affected due irradiation up to $500 \mathrm{kGy}$.

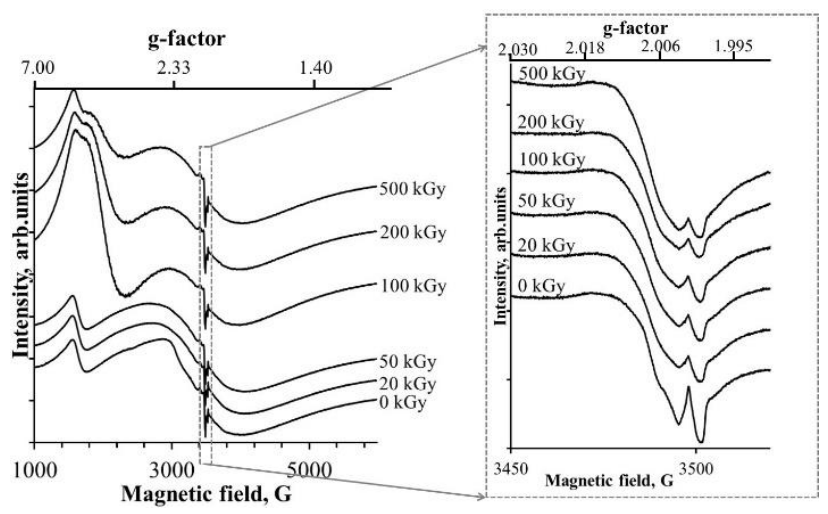

Fig. 7. ESR spectra of $2 \mu \mathrm{m}$ clay fraction before irradiation and irradiated with absorbed doses up to $500 \mathrm{kGy}$

The main radiation effect occurs at the absorbed doe $100 \mathrm{kGy}$, where and additional ESR signal occurs with $\mathrm{g}=3.5$, that shows, that $2 \mu \mathrm{m}$ clay are radiation stable below absorbed doses $100 \mathrm{kGy}$.

\section{CONCLUSIONS}

Characterization of content, chemical bonds and paramagnetic centres in two differently prepared Latvian natural Liepa clay fractions is performed. The main differences between both fractions are due to presence of silicon oxide. Irradiation under action of accelerated electrons up to absorbed doses $500 \mathrm{kGy}$ does not cause detectable changes in the Liepa clay. The obtained results about the physic-chemical properties of the various fractions of the Latvian clays can be used for application of these clays for isotope sorption. 


\section{Acknowledgments}

The work is performed in the frames of the University of Latvia financed project No. Y9-B044-ZF-N-300, "Nano, Quantum Technologies, and Innovative Materials for Economics".

\section{REFERENCES}

1. Certoks, S., Svinka, R., Svinka, V. Influence of Pore Forming Additives on Phase Formation Processes and Properties of Thermal Insulating Building Ceramic Materiālzinātne un Lietiškā Kīmija 11 2005: pp. 91-100.

2. Krstic, V., Urosevic, T., Pesovski, B. A Review on Adsorbents for Treatment of Water and Wastewaters Containing Copper Ions Chemica Engineering Science 192 2018: pp. $273-287$.

https://doi.org/10.1016/j.ces.2018.07.022

3. Kraukls, A., Ozola, R., Burlakovs, J., Rugele, K., Kirillov, K., $\quad$ Trubaca-Boginska, A., $\quad$ Rubenis, K., Stepanova, V., Klavins, $\mathrm{M}$. $\mathrm{FeOOH}$ and $\mathrm{Mn}_{8} \mathrm{O}_{10} \mathrm{C}_{13}$ Modified Zeolites for As(V) Removal in Aqueous Medium Journal of Chemical Technology and Biotechnology 92 (8) 2017: pp. $1948-1960$.

https://onlinelibrary.wiley.com/doi/abs/10.1002/jctb.5283

4. Comans, R.N.J., Haller, M., De Preter, P. Sorption of Caesium on Illite: Non-equilibrium Behaviour and Reversibility Geochimica et Cosmochimica Acta 55 1991: pp. $433-440$. https://doi.org/10.1016/0016-7037(92)90053-L

5. Barraque, F., Montes, M.L., Fernandez, M.A., Mercander, R.C., Candal, R.J., Torres Sancez, R.M. Synthesis and Characterization of Magnetic-Montmorillite and Magnetic-Organo-Montmorillite: Surface Sites Involved in Cobalt Sorption Journal of Magnetism and Magnetic Materials 466 2018: pp. 376-384. https://doi.org/10.1016/j.jmmm.2018.07.052

6. Ou, J., Li, H., Yan, Z., Zhou, Y., Bai, L., Zhang, Ch., Wang, X., Chen, G. In Situ Immobilization of Toxic Metals in Soil Using Maifan Stone and Illite/Smectite Clay Scientific Reports 8 (4618) 2018: pp. 1-9. https://doi.org/10.1038/s41598-018-22901-w

7. Trubaca-Boginska, A., Adina, R., Vaivars, G., Svirksts, J. A Study of Acidification and Intercalation of Illite Clay Minerals and Their Potential Use as a Filler in SPEEK Composite Membranes Key Engineering Materials 762 2018: pp. 186-191. https://doi.org/10.4028/www.scientific.net/KEM.762.186

8. Lopez-Galindo, A., Fenoll Hach-Ali, P., Pushkarev, A.V., Lytovchenko, A.S., Baker, J.H., Pushkarova, R.A. Tritium Redistribution Between Water and Clay Minerals Applied Clay Science 39 2008: pp. 151-159. https://doi.org/10.1016/j.clay.2007.06.005

9. Sahoo, S.K. Characterization of $\gamma$ - and $\alpha-\mathrm{Fe}_{2} \mathrm{O}_{3} \mathrm{Nano}$ Powder Synthesized by Emulsion Precipitation - Calcination Route and Rheological Behaviour of $\alpha-\mathrm{Fe}_{2} \mathrm{O}_{3}$ International Journal of Engineering, Science and Technology 2-8 2010: pp. $118-126$. https://doi.org/10.4314/ijest.v2i8.63841

10. Zhang, X., Niu Y., Meng X., Li Y., Zhao J., Structural Evolution and Characteristics of the Phase Transformations Between $\alpha-\mathrm{Fe}_{2} \mathrm{O}_{3}, \mathrm{Fe}_{3} \mathrm{O}_{4}$ and $\gamma-\mathrm{Fe}_{2} \mathrm{O}_{3}$ Nanoparticles Under Reducing and Oxidizing Atmosphere, Electronic Supplementary Information (ESI) The Royal Society of Chemistry 2013: pp. S1-S6.

11. Database of ATR-FT-IR spectra of various materials http://lisa.chem.ut.ee/IR_spectra/paint/fillers/aluminiumoxide/

12. Kandiban, M., Vigneshwaran, P., Vetha Potheher, I., Synthesis and Characterization of $\mathrm{MgO}$ Nanoparticles for Photocatalytic Applications, Department of Physics, Bharathidasan Institute of Technology (BIT) Campus, Anna University, Tiruchirappalli, Tamilnadu, India, Conference Paper, 2015.

13. Gourley, J.T., Runciman, W.A. Multiphonon Infrared Absorption Spectra of $\mathrm{MgO}$ and $\mathrm{CaO}$ Journal of Physics C: Solid State Physics 6 (3) 1973: pp. 583-592 https://doi.org/10.1088/0022-3719/6/3/021

14. Rafiqul Ahsan, M., Alfaz Uddin M., Golam Mortuza M., Infrared Study of the Effect on $\mathrm{P}_{2} \mathrm{O}_{5}$ in the Structure of Lead Silicate Glasses Indian Journal of Pure \& Applied Sciences 43 2005: pp. 89-99.

15. Grujic-Brojcin, M., Scepanovic, M.J., DohčevićMitrović, Z., Popovic, Z. Infrared Study of Laser Synthesized Anatase $\mathrm{TiO}_{2}$ Nanopowders Journal of Physics. D: Appllied Physics 38 2005: pp. 1415-1420. https://doi.org/10.1088/0022-3727/38/9/014

16. Kaliprasad, C.S., Vinutha, P.R., Narayana, Y. Studies on Distribution of Radionuclides and Behaviour of Clay Minerals in the Soils of River Environs Journal of Radioanalytical and Nuclear Chemistry 316 2018: pp. 609-617. https://doi.org/10.1007/s10967-018-5825-1

17. Mota, L., Toledo, R., Faria, R.T., de Silva, E.C., Vargas, H., Delgadillo-Holtfort, I. Thermally Treated Clays as Ceramic Raw Materials: Characterization by X-ray Diffraction, Photoacoustic Spectroscopy and Electron Spin Resonance Applied Clay Science 43 2009: pp. 243-247. https://doi.org/10.1016/j.clay.2008.07.025

18. Riegler, T., Allard, T., Beaufort, D., Cantin, J.L., von Bardeleben, H.J. Thermal Stability of Radiation Induced Defects in Illite Physics and Chemistry of Minerals 43 2016: pp. 23-30. https://doi.org/10.1007/s00269-015-0770-9

19. Allard, Th., Calas, G. Radiation Effects on Clay Mineral Properties Applied Clay Science 43 2011: pp.143-149.

20. Allard, Th., Balan, E., Calas, G., $\quad$ Fourdrin, C., Morichon, E., Sorieul, S. Radiation-Induced Defects in Clay Minerals: A Review Nuclear Instruments and Methods in Physics Research B 277 2012: pp. 112-120. https://doi.org/10.1016/j.nimb.2011.12.044 